\title{
Psychiatric Comorbidities of Epilepsy: A Review
}

\section{José Augusto Bragatti*, Carolina Machado Torres, Gustavo Rassier Isolan and Marino Muxfeldt Bianchin}

Division of Neurology, Hospital de Clínicas de Porto Alegre

\begin{abstract}
People with epilepsy (PWE) have an increased risk for cognitive, behavioral, and psychosocial disorders. The presence of comorbidities may directly affect quality of life of PWE. For example, there is an increased risk for suicide in PWE, compared to the general population. Association between epilepsy and mental disorders is a condition known since Antiquity, and its ranges from 20 to $50 \%$, reaching $80 \%$ in selected populations, like individuals with temporal lobe epilepsy (TLE), and medically intractable patients, candidates to surgical treatment, and these indices are far superior to those found in general population (10-20\%). Risk factors for the main psychiatric comorbidities in PWE (depression, anxiety and psychosis) are classified in (1) neurobiological, (2) psychosocial, and (3) pharmacological factors. There is a bidirectional relationship between epilepsy and mental disorders, namely, not only the epileptic disorder can antedate settlement of psychiatric symptoms in a given patient, but also the diagnosis of mood and behavioral disorders may be made before a first epileptic seizure. This bidirectionality suggests that structural and functional modifications of one disease increase the risk for the development of the other. In this review, we included the most recent articles concerning the terms "mental disorders", "epilepsy", and "risk factors" in PubMed. Book chapters were also referred for this work. We gave preference for population-based studies, especially those with more than 100 patients studied.
\end{abstract}

Keywords: Epilepsy; Comorbidity; Mental disorders; Risk factors; Physiopathology

\section{Introduction}

Ian Curtis, the famous Joy Division band's vocalist and song writer had a transient personality. He could show different behaviors at different times and with different people. Sometimes he was angry and spiteful, but more often was compliant and kind. He was diagnosed as epileptic when he was 23 years old. His fits varied in frequency and intensity, and anticonvulsant medication, which he took regularly, seemed to make his mood swings more radically. His frenetic style on stage simulated his own real epileptic seizures. Ian Curtis killed himself at his home in Macclesfield, England. He was 24 years old. The history of his life was recently portrayed in the movies "Control", launched in 2007 [1].

This case exemplifies how an epileptic disorder can transform people's lives in true tragedies, harming their quality of life, changing personality traits and eventually increasing malady and causing death. Epilepsy is quite common also in "anonimous" individuals, and comprehension of its comorbidities, especially those pertaining to the psychiatric sphere, is a basic element for its management.

Epilepsy is a frequent neurological disorder with a worldwide distribution, although most people with epilepsy (PWE) live in underdeveloped countries. The term Epilepsy comprises many conditions typified by a tendency to spontaneous recurrence of epileptic seizures. Epilepsy occurs in all ages and can be associated to several cognitive, social and psychiatric troubles [2].

Epileptic seizures are clinical expressions (symptoms) that begin abruptly and have a great variability in presentation form. A seizure can present with motor, sensorial, autonomic and/or state of consciousness changes [3]. The common physiopathological substrate for all types of epileptic seizures is disequilibrium between excitatory and inhibitory influences onsettled neuronal pathways. In summary, there is a state of hyperexcitability supplied by predominant excitatory strengths. Epilepsies and epileptic seizures are divided in generalized (when neuronal hyperexcitability originates in both cerebral hemispheres simultaneously) and focal (localized unilateral neuronal hyperexcitability) $[4,5]$.

The most common epileptic disorder is the Temporal Lobe Epilepsy (TLE) that afflicts $40 \%$ of adult PWE [6]. Temporal lobe seizures belong to three distinct types: simple partial (aura only), complex partial (most commonly absences with automatisms), and secondarily generalized. TLE is divided in mesial (onset on hippocampus and amygdala) and lateral (onset on temporal neocortex). Mesial TLE has high indices of association with psychiatric disorders, because it involves the Lymbic System, the main integrator of emotional processes $[7,8]$. The most common pathology causing mesial TLE is hippocampal sclerosis [3].

The epileptic seizure temporally subdivides the clinical state of the PWE into two distinct periods of time: ictal (or peri-ictal) and interictal (when there isn't any sustained-release excessive rhythmic neuronal discharge). The essential focus of pharmacologic treatment of epilepsy is the hamper of ictal phenomenon. In general, this is achieved in about two thirds of cases [2]. Nevertheless, study of the interictal condition of PWE is also very important, and has improved the comprehension of epileptic phenomenon as a whole.

One of the most important issues not linked to the pharmocological control of seizures is the assessment of comorbidities in PWE. These patients have an increased risk for cognitive, behavioral, and psychosocial disorders. [8,9] By the way, not only a poor control of

*Corresponding author: José Augusto Bragatti, Division of Neurology, Hospital de Clínicas de Porto Alegre, Brazil, Tel: +5551-3222-4690; Fax: +5551-32224690; E-mail: jbragatti@hcpa.ufrgs.br

Received July 24, 2011; Accepted December 09, 2011; Published December 18, 2011

Citation: Bragatti JA, Torres CM, Isolan GR, Bianchin MM (2011) Psychiatric Comorbidities of Epilepsy: A Review. J Neurol Neurophysiol S2. doi:10.4172/21559562.S2-002

Copyright: (c) 2011 Bragatti JA, et al. This is an open-access article distributed under the terms of the Creative Commons Attribution License, which permits unrestricted use, distribution, and reproduction in any medium, provided the original author and source are credited. 
seizures, but also the presence of comorbidities may directly affect quality of life of PWE. There is an increased risk for suicide in PWE, compared to the general population, and this risk is even greater in patients with a history of a psychiatric disorder, especially with the association between depression and anxiety [10].

Epilepsy associated with mental disorders is a condition already known since Antiquity. Most part of stigma that follows PWE is descendent from the assignment of supernatural entities, like gods, witches, and devils, to the epileptic disorder [11].

Prevalence of the association of epilepsy and psychiatric disorders ranges from 20 to $50 \%$, reaching $80 \%$ in selected populations like individuals with TLE, and medically intractable patients, candidates to surgical treatment. These indices are far superior to those found in general population (10-20\%). Differences in methods of investigation and in populations studied are the main contributory factors for variable results. Also distinct epidemiological definitions (punctual prevalence, cumulative prevalence, lifelong prevalence), with their proper meanings, may contribute equally to variability of results $[12,13]$.

Risk factors for the main psychiatric comorbidities in PWE (depression, anxiety and psychosis) are classified in (1) neurobiological, (2) psychosocial, and (3) pharmacological factors. Major neurobiological factors are: type, frequency, duration, age of onset, and lateralization of epileptic seizure, genetic predisposition, gender, and presence of structural lesion. Issues concerning surgical treatment of epilepsy, like lateralization, type of resection, histopathological diagnosis, and surgical prognosis have been studied also. Other factors like hippocampal volume loss, temporal and frontal lobe glucose hypometabolism, and neurotransmitter and hormonal substances changes, may also be highlighted. As psychosocial factors we could name the "learned despair", restraints to normal daily living activities, low self-esteem, educational and Professional difficulties, stigmatization, and social rejection. Among pharmacological factors, adverse effects of central nervous system (CNS) depressor antiepileptic drugs (DAEs), withdrawal of a mood stabilizer drug, polytherapy, starting a new DAE, and dose adjusting have been cited [14,15].

There is a heterogeneous association between epilepsy subgroups and psychiatric disorders. In most patients, several chronic and acute risk factors can be identified. These factors are difficult to study retrospectively, and establishment of a cause and effect relationship may not always be possible. Literature data is highly controversial, and there is a huge difficulty to compare studies, because of the great variability in definition of essential terms like "epilepsy", "psychiatric disorder", and the proper explored risk factors.

It is important to highlight that there isn't a unidirectional relationship between epilepsy and mental disorders, namely, not only the epileptic disorder can antedate settlement of psychiatric symptoms in a given patient, but also the diagnosis of mood and behavioral disorders may be made before a first epileptic seizure. This bidirectionality suggests that structural and functional modifications of one disease increase the risk for the development of the other [16].

There is increasing evidence that both in epilepsy and in mental disorders, changes in interaction between serotonergic and noradrenergic neurons with glutamatergic systems are associated to abnormal neuronal circuitries and hyperexcitability. This hyperexcitability could evoke both seizure activity and emotional dysfunctions [15]. Furthermore, decrease in synaptic levels of neurotransmitters, as well as elevation in glucocorticoid levels could influence intracellular signaling pathways, like cyclic Adenosine Monophosphate (cAMP), and originating disorders of neurotrophic factors, like Brain-Derived eurotrophic Factor (BDNF) [17,18]

Therefore, the association between TLE and psychiatric disorders seems to be highly prevalent. This comorbidity affects directly clinical prognosis of the epileptic seizures, and also the quality of life of the patients with this type of epilepsy. It appears that there are common physiopathological mechanisms in both TLE and mental disorders, in general affecting neuronal circuitries of Lymbic System. Genetic disorders, like polymorphisms of receptor genes of many neurotransmitters, and also of neurotrophins, like BDNF, might be involved in this association.

In this review, we included the most recent articles concerning the terms "mental disorders", "epilepsy", and "risk factors" in PubMed. Book chapters were also referred for this work. We gave preference for population-based studies, especially those with more than 100 patients studied.

\section{Concepts in Epilepsy}

The term Epilepsy comprises several syndromes which the main characteristic is an enduring redisposition to recurrent non-provoked epileptic seizures [2]. Epileptic seizures are sudden and brief attacks of altered consciousness, motor, sensitive, psychic, cognitive or autonomic dysfunctions, or an inappropriate behavior, caused by excessive or synchronic abnormal neuronal activity in the brain [3].

The epilepsies and epileptic seizures are classified in focal and generalized [4,5]. Regarding focal epilepsies, the seizure clinical expression is determined by the topographical localization of the neuronal discharge, as well as its extent of spread in the brain. For the sake of conceptualization and pre-surgical neurophysiologic assessment of epilepsies, the region that yields the neuronal discharge is named Ictal Onset Zone, and the regions that generate the seizure's clinical features are named Symptomatogenic Zones. This is an important distinction, because the region where the discharge starts is not always able to produce clinical manifestations ("silent cortex"). In this case, surgical removal of the symptomatogenic zone would not be curative, because the real source of the epileptic disorder would not be included in the removed tissue [19]. The physiopathology of generalized seizures is diverse, depending on a genetically-determined thalamocortical circuitry dysfunction [20].

Regarding etiology, epilepsies are divided in idiopathic (without structural brain lesion), symptomatic (with a structural lesion seen in neuroimaging exams) and cryptogenic (with a presumable etiology, not diagnosed at all) [5]. Estimated incidence of epilepsy in developed countries is about 50/100,000/year [21], and these numbers may double in poor countries [22]. In general, we find a bimodal distribution, with peaks of incidence in the first year of life and after 60 years of age. Prevalence of active epilepsy in most regions of the world is in turn of 5-10/1,000, although it may be even greater in some localized areas $[23,24]$. General prognosis for complete seizure control is good, since $70 \%$ of patients acquire remission after five years of diagnosis $[25,26]$. Nevertheless, both adults and children with epilepsy an increased risk for death, when compared with normal individuals [27,28].

\section{Temporal Lobe Epilepsy}

Temporal lobe epilepsy represents most patients with symptomatic or cryptogenic focal epilepsies. Types of seizures in TLE include simple 
partial, complex partial and secondarily generalized seizures. Seizures most often originate in amygdalo-hippocampal region, in the medial and basal portion of temporal lobe. Hence, mesial temporal epilepsy (MTE) is the most frequent focal epilepsy [29-32].

In MTE, seizure begins in more than $90 \%$ of the cases with an unnatural rising epigastric sensation. Other autonomic, psychic (i.e.: fear) and sensitive (i.e.: olfactory sensation) symptoms could occur also. Complex partial seizures of MTE almost always implicate motor arrest or automatisms (oroalimentary or gestural), early in the course of seizure. Ictal features with lateralizatory value include: dystonic posture of one superior limb (contralateral to the epileptic focus), early shift of the head (ipsilateral), late version of head, on transition to secondary generalization (contralateral). Intelligible vocalizations suggest onset of seizure in the non-dominant hemisphere. Most often, temporal lobe seizures last about two minutes, and are followed by a post-ictal confusional state. Post-ictal aphasia suggests seizure activity in the dominant hemisphere. MTE is the most common medically refractory focal epilepsy, and also one of the most surgically treatable [33].

Lateral (neocortical) TLE is less frequent, and generally is characterized by an auditory aura [34]. Most often, seizures yielded in the lateral portion of temporal lobe are shorter in duration. Vertiginous hallucinations were described with temporo-parietal discharges.

Most frequently structural lesions associated with TLE are: hippocampal sclerosis, benign tumors (i.e.: ganglioglioma, neuroepithelial dysembrioplasic tumors), vascular malformations (i.e.: cavernoma), and malformations of cortical development (i.e.: focal cortical dysplasia). Hippocampal sclerosis coexisting with an extratemporal lesion is called dual pathology, a condition that carries a greater degree of difficulty for diagnosis, and worst prognosis [35].

Considering the importance of limbic circuitries for the neuropsychiatric diseases, it is not a surprise the observation that many patients with TLE present concomitant psychiatric disorders, like depression and anxiety [36].

\section{Comorbidities in Epilepsy}

The term comorbidity refers to a more than occasional concomitant presence of two medical conditions in the same individual [37]. Comorbidity does not implies directionality or a cause-and-effect relationship, and diseases may coexist randomly, or also share common genetic and/or environmental mechanisms [9]. Epilepsy is frequently associated to cognitive, psychiatric or social troubles [38].

\section{Psychiatric Comorbidities in Epilepsy}

\section{Historical}

Association between epilepsy and psychiatric disorders has been described since the beginnings of Neurology and Psychiatry practices, and there are many examples found in literature. Hippocrates, about 400 b.c., observed a dichotomy between epilepsy and melancholia, and purposed that these two entities could be linked by a probable common physiopathological mechanism [11].

The history of the epilepsy-psychiatry interface had its beginning imprinted by the empirical association of these conditions with gods, witches, devils, and supernatural phenomena. The Greeks referred to epilepsy as the "sacred disease". In those years, Hippocrates that rush of fury that led Hercules to kill his children had an epileptic nature. The Romans referred to epilepsy as "morbidus lunaticus", related to the different phases of the moon. In the Arabic world, the epilepsy-mental disorders-devils association persisted, and prophets, like Mohammed and Saint Paul, that periodically heard voices and fell on the floor, supposedly had epilepsy [39].

In the XIX ${ }^{\text {th }}$ century and in the beginning of the $\mathrm{XX}^{\text {th }}$ century, epilepsy was a common diagnosis in asylums housing patients with mental disorders. The most sicker individuals were treated by psychiatrists, whereas those with less severe pictures stayed in the community, where they were treated by general physicians or neurologists [40].

In the 1920's decade, Emil Kraepelin made observations that are considered the basis for the modern psychiatric diagnostic classification. Kraepelin described precisely the affective changes of PWE, years before the age of electroconvulsive therapy. Dysphoric events, characterized by irritability, with or without bursts of fury, were considered by him the most frequent psychiatric disorder in PWE. Depression, anxiety, headache, and insomnia were very frequent complementary symptoms, although euphoric mood was less common [41].

Heinrich Landolt identified different types of psychotic episodes and their correlations with epileptic seizures and the electroencephalogram (EEG), introducing the concept of "Alternant Psychosis or Forced Normalization" [42]. His work was later complemented by Slater and Beard, with the article "Schizophrenia-Like Psychosis of Epilepsy", where it was purposed an agonic relation between epileptic seizures and psychotic states [43].

More recently, the introduction of advanced techniques of neuroimaging, like Positron Emission Tomography (PET), Magnetic Resonance Imaging (MRI), and the spectroscopy, combined with animal models and refined behavioral tests, made it possible the identification of common physiopathological mechanisms to both the epilepsies (especially TLE) and psychiatric disorders (especially major epression).

\section{Epidemiology}

There are few community-based studies on prevalence of psychiatric conditions in PWE. Most of these studies involve specific epileptic populations, in tertiary centers for attention to PWE. Community-based epidemiologic studies suggest a lifelong prevalence of psychiatric disorders in PWE, both adults and children, between 20 and 50\% [13,44-52]. Recently, Tellez-Zenteno et al. [9] using data from the Canadian Community Health Survey, with administration of the World Mental Health Composite International Diagnostic Interview (CIDI), found a lifelong psychiatric disorder diagnosis in 35\% of PWE, compared with $20 \%$ of non-epileptic individuals.

The great variability of results obtained has been ascribed to differences in the methodology applied and in populations studied. It is well known that psychiatric pathologies could be overrated in selected populations, like TLE or refractory patients [53], in whose prevalence of mental disorders may reach $80 \%$ [54].

\section{Methods of psychiatric assessment}

Psychiatric assessment can be made basically by two types of interviews: structured interviews and self-applicable questionnaires (non-structured) [12]. Non-structured interviews have been progressively replaced by structured interviews in the last years, to obtain a greater diagnostic accuracy. Structured interviews are composed by a 
set of key questions intending the fulfillment of well-defined diagnostic criteria included in the Diagnostic and Statistical Manual, Fourth Edition (DSM-IV). Main representatives are the Structured Clinical Interview for DSM Disorders (SCID) [55] and the Mini-International euro psychiatric Interview (MINI) [56]. Self-applicable questionnaires, like the Beck Depression Inventory (BDI) [57], and the Center for Epidemiologic Studies Depression Scale (CES-D) [58], in general are less extensive and are based upon subjective criteria. Results obtained by self-applicable tests tend to be overrated regarding prevalence of psychiatric disorders.

Nevertheless, studies of lifelong prevalence of psychiatric disorders in PWE point to upper indices, compared to those found in general population [59]. For a comparison between several studies, see Tables 1 and 2. In community-based studies (Table 1), prevalences varied between $5.9 \%$ e $54.5 \%$. Only one study (Davies et al.) used structured interview for psychiatric diagnosis. This study found a superior number (37\%), compared with other older population-based studies that used unstructured interviews. Regarding studies of selected populations (performed in tertiary centers, in general as part of a presurgical evaluation), prevalence varied between $6.7 \%$ and $80 \%$. Clearly, patients with difficult-to-control seizures, and especially those studied with structured interviews, trend to show increased frequencies of psychiatric comorbidities.

\section{Risk factors}

Many papers have been demonstrated that patients with TLE have an increased risk for psychiatric disorders, when compared to patients with other non-neurological chronic diseases [7,38,54,60]. Notwithstanding, it is still controversial if patients with TLE have increased risk for development of a mental disorder when compared with patients with other types of epilepsy. Two important studies didn't find any differences in the risk of patients with TLE, focal extratemporal, and idiopathic generalized epilepsies [61,62]. It is possible that greater prevalence of psychiatric disorders in patients with TLE could depict just the dominant prevalence of TLE related to other epilepsies [63].

Despite this conjecture, it is plausible to believe that the same neuronal circuitries involved in the physiopathogenic mechanisms of TLE are also responsible for the production of psychiatric symptoms [15]. Purposed mechanisms for this frequent association could be arbitrarily divided in clinical, biological and environmental causes. Regarding clinical factors, it has been enrolled: number of epileptic seizures since onset of disease, effects of antiepileptic drugs, lateralization of the epileptic focus, gender and psychiatric familial history [8].

Biological factors concern chemical and structural changes in the Lymbic System circuitry, the site of processing of behavior and emotions [14]. Environmental factors possibly involved with psychiatric comorbidities in epilepsy include: loss of independence, social stigma, financial and legal restraints (i.e.: driving license) [64]. In a prospective study achieved in the New York University, Devinsky et al. assessed the impact of several clinical variables on the quality of life of patients with intractable epilepsy, in pre-surgical evaluation. Presence of depression, assessed by the BDI, was the only predictive factor for

\begin{tabular}{|c|c|c|c|c|c|c|c|c|}
\hline AUTHORS & $\mathrm{N}$ & INSTRUMENT & POPULATION & $\begin{array}{c}\text { PSYCHIATRIC } \\
\text { DISORDERS }\end{array}$ & $\begin{array}{c}\text { MOOD } \\
\text { DISORDERS }\end{array}$ & $\begin{array}{c}\text { ANXIETY } \\
\text { DISORDERS }\end{array}$ & PSYCHOSIS & $\begin{array}{c}\text { SUBSTANCEE } \\
\text { ABUSE }\end{array}$ \\
\hline $\begin{array}{c}\text { Pond and } \\
\text { Bidwell, } 1960 \\
\text { UK }\end{array}$ & 245 & $\begin{array}{l}\text { Unstructured } \\
\text { psychiatric } \\
\text { interview }\end{array}$ & $\begin{array}{c}\text { Children with } \\
\text { epilepsy - } \\
\text { community-based }\end{array}$ & $29 \%$ & - & - & - & - \\
\hline $\begin{array}{c}\text { Gudmundsson, } \\
1966 \\
\text { Iceland }\end{array}$ & 654 & $\begin{array}{l}\text { Clinical interview } \\
\text { (unstructured) }\end{array}$ & $\begin{array}{c}\text { Epilepsy } \\
\text { (communitybased) }\end{array}$ & $54.5 \%$ & - & - & $9 \%$ & - \\
\hline $\begin{array}{c}\text { Graham and } \\
\text { Rutter, } 1970 \\
\text { UK }\end{array}$ & 63 & $\begin{array}{l}\text { Unstructured } \\
\text { psychiatric } \\
\text { interview }\end{array}$ & $\begin{array}{c}\text { Children with } \\
\text { epilepsy - } \\
\text { community-based }\end{array}$ & $28.6 \%$ & - & - & - & - \\
\hline $\begin{array}{l}\text { Forsgren, } 1992 \\
\quad \text { Sweden }\end{array}$ & 713 & $\begin{array}{l}\text { Chart review } \\
\text { (unstructured) }\end{array}$ & $\begin{array}{c}\text { Epilepsy - } \\
\text { community-based }\end{array}$ & $5.9 \%$ & - & - & $0.7 \%$ & - \\
\hline $\begin{array}{c}\text { Bredkjaer et al., } \\
1998 \\
\text { Denmark }\end{array}$ & 67 & ICD-8 & $\begin{array}{c}\text { Epilepsy- } \\
\text { community-based }\end{array}$ & $16.8 \%$ & - & - & - & - \\
\hline $\begin{array}{c}\text { Hackett et al., } \\
1998 \\
\text { India }\end{array}$ & 26 & ICD-10 & $\begin{array}{c}\text { Epilepsy- } \\
\text { community-based }\end{array}$ & $23.1 \%$ & - & - & - & - \\
\hline $\begin{array}{c}\text { Davies et al., } \\
2003 \\
\text { UK }\end{array}$ & 67 & SCID & $\begin{array}{c}\text { Epilepsy- } \\
\text { community-based }\end{array}$ & $37 \%$ & - & - & - & - \\
\hline $\begin{array}{c}\text { Ettinger et al., } \\
2004 \\
\text { USA }\end{array}$ & 775 & CES-D & $\begin{array}{c}\text { Epilepsy - } \\
\text { community-based }\end{array}$ & - & $36.5 \%$ & - & - & - \\
\hline $\begin{array}{c}\text { Strine et al., } \\
2005 \\
\text { USA }\end{array}$ & 427 & Kessler 6 scale & $\begin{array}{c}\text { Epilepsy - } \\
\text { community-based }\end{array}$ & - & $32.6 \%$ & $14.4 \%$ & - & - \\
\hline $\begin{array}{c}\text { Kobau et al., } \\
2006 \\
\text { USA }\end{array}$ & 131 & $\begin{array}{c}\text { Health Style Survey } \\
\text { (self- reported } \\
\text { depression and } \\
\text { anxiety) }\end{array}$ & $\begin{array}{c}\text { Epilepsy - } \\
\text { community-based }\end{array}$ & - & $39 \%$ & $39 \%$ & - & - \\
\hline $\begin{array}{l}\text { Tellez-Zenteno } \\
\text { et al., } 2007 \\
\text { Canada }\end{array}$ & 253 & CIDI & $\begin{array}{c}\text { Epilepsy - } \\
\text { community-based }\end{array}$ & $23.5 \%$ & $17.4 \%$ & $12.8 \%$ & - & - \\
\hline
\end{tabular}

Table 1: Prevalence of psychiatric comorbidities in PWE. Population-based studies. 
Citation: Bragatti JA, Torres CM, Isolan GR, Bianchin MM (2011) Psychiatric Comorbidities of Epilepsy: A Review. J Neurol Neurophysiol S2. doi:10.4172/2155-9562.S2-002

Page 5 of 10

\begin{tabular}{|c|c|c|c|c|c|c|c|c|}
\hline $\begin{array}{c}\text { Edeh and Toone, } \\
1987 \\
\text { UK }\end{array}$ & 88 & CIS & $\begin{array}{c}\text { Epilepsy - selected } \\
\text { by } \\
\text { general practitioners } \\
\text { (GP) }\end{array}$ & $48 \%$ & $22 \%$ & $15 \%$ & $3.4 \%$ & - \\
\hline $\begin{array}{c}\text { Gaitatzis et al., } \\
2004 \\
\text { UK }\end{array}$ & 5834 & ICD-9 & $\begin{array}{l}\text { Epilepsy - selected } \\
\text { from a database } \\
\text { generated by GP }\end{array}$ & $41 \%$ & $18.2 \%$ & $11.1 \%$ & $9 \%$ & $2.4 \%$ \\
\hline $\begin{array}{c}\text { Mensah et al., } \\
2006 \\
\text { UK }\end{array}$ & 499 & HADS & Epilepsy - from GP & - & $11.2 \%$ & - & - & - \\
\hline $\begin{array}{l}\text { Perini et al., } 1996 \\
\text { Italia }\end{array}$ & 38 & $\begin{array}{c}\text { SADS, BDI, } \\
\text { STAIX1, STAIX2 }\end{array}$ & $\begin{array}{l}\text { JME and TLE } \\
\text { (selected) } \\
\text { patients }\end{array}$ & $\begin{array}{l}\text { 80\% (TLE), } \\
22 \% \text { (JME) }\end{array}$ & $\begin{array}{l}55 \% \text { (TLE), } \\
17 \% \text { (JME) }\end{array}$ & $\begin{array}{l}15 \% \text { (TLE), } \\
11 \% \text { (JME) }\end{array}$ & - & - \\
\hline $\begin{array}{c}\text { Swinkels et al., } \\
2001 \\
\text { Netherlands }\end{array}$ & 209 & CIDI & $\begin{array}{l}\text { Epilepsy - tertiary } \\
\text { epilepsy center }\end{array}$ & - & $24.9 \%$ & $29.7 \%$ & $0.5 \%$ & $0.5 \% 20.1 \%$ \\
\hline $\begin{array}{l}\text { Havlová, } 1990 \\
\text { Czech Republic }\end{array}$ & 225 & $\begin{array}{l}\text { Chart review } \\
\text { (unstructured) }\end{array}$ & $\begin{array}{l}\text { Cohort of epileptic } \\
\text { children }\end{array}$ & $6.7 \%$ & - & - & - & - \\
\hline $\begin{array}{c}\text { Stefansson et al., } \\
1998 \\
\text { Iceland }\end{array}$ & 241 & ICD-9 & $\begin{array}{l}\text { Epileptic patients } \\
\text { receiving benefits }\end{array}$ & $35.3 \%$ & - & - & $6.2 \%$ & $5 \%$ \\
\hline $\begin{array}{c}\text { Jalava and } \\
\text { Sillanpaa, } 1996 \\
\text { Finland }\end{array}$ & 94 & $\begin{array}{c}\text { Chart review and } \\
\text { ICD-9 }\end{array}$ & $\begin{array}{l}\text { Epilepsy - selected } \\
\text { from } \\
\text { different sources }\end{array}$ & $24 \%$ & - & - & $3.1 \%$ & - \\
\hline $\begin{array}{c}\text { Gureje et al., } \\
1991 \\
\text { Nigeria }\end{array}$ & 204 & CIS & $\begin{array}{l}\text { Epilepsy - tertiary } \\
\text { center }\end{array}$ & $37 \%$ & - & - & $30 \%$ & - \\
\hline $\begin{array}{l}\text { Araújo Filho et } \\
\text { al., } 2008 \\
\text { Brazil }\end{array}$ & 270 & SCID & $\begin{array}{c}\text { Refractory TLE and } \\
\text { JME } \\
\text { from a tertiary } \\
\text { epilepsy center }\end{array}$ & $\begin{array}{l}50 \% \text { (TLE), } \\
49 \% \text { (JME) }\end{array}$ & $\begin{array}{c}25.8 \%(\text { TLE) } \\
\text { 19\% (JME) }\end{array}$ & $\begin{array}{c}\text { 14.1\% (TLE), } \\
\text { 23\% (JME) }\end{array}$ & $\begin{array}{c}\text { 15.8\% (TLE), } \\
\text { 3\% (JME) }\end{array}$ & $\begin{array}{l}2 \% \\
(\mathrm{JME})\end{array}$ \\
\hline $\begin{array}{c}\text { Bragatti et al., in } \\
\text { press } \\
\text { Brazil }\end{array}$ & 98 & SCID & $\begin{array}{c}\text { TLE - selected from } \\
\text { a tertiary epilepsy } \\
\text { center }\end{array}$ & $54.1 \%$ & $42.9 \%$ & $18.4 \%$ & $6.1 \%$ & $6.1 \%$ \\
\hline
\end{tabular}

Table 2: Prevalence psychiatric comorbidities in PWE. Studies in selected populations.

achievement of low indices of quality of life, assessed by the Quality of Life in Epilepsy (QOLIE-31) survey. Neither other factor (frequency of seizures, localization, age, gender, marital status, duration and type of seizure, or number of DAE) was predictor for quality of life [65].

PWE have a significantly increased risk for suicide related to general population. Two big studies, made in Canada [9] and Denmark [10], showed that PWE has 2 to 3 times more risk of suicide than control individuals. Danish study found a risk of suicide even greater between epileptic patients with a specific comorbidity: mood disorder plus anxiety.

\section{Specific Psychiatric Disorders}

\section{Mood disorders}

Main neurobiological risk factors for depression in PWE that has been studied are: lateralization of epileptic focus, frontal lobe hypometabolism, and hippocampal volume.

Regarding lateralization, Hurwitz et al. [66] found association between left-sided epileptic focus and depressive mood. In this study, seizures yielded by the right hemisphere were followed by laughter and seductive behavior. As a seizure activity localized in one hemisphere probably "releases" the opposite hemisphere, the authors postulated that the dominant hemisphere could be responsible for negative emotional states, and the non-dominant hemisphere could yield the opposite effect. Other theory hypothesizes that a seizure activity in the non-dominant hemisphere could result in neglect of negative emotions [63]. Many controlled studies comparing seizure focus with degrees of depression found increased frequencies of depression with a focus in the left hemisphere, independent of seizure type [67-70], although other studies didn't ratify this correlation [71]. A complex interaction between several factors would be employed in this association.

Recent works using PET and SPECT have shown an association between epilepsy and frontal lobe dysfunction with hypo metabolism. Bromfield et al. [72] studied 23 patients with complex partial seizures, candidates for surgery, regarding depressive features (BDI > 11), compared to normal controls. Patients with a left-sided temporal focus presented more depressive symptoms as well as a bilateral inferior frontal lobe hypo metabolism. Victor off et al. [70] studying 53 epileptic patients candidates for surgical treatment, observed that an ictal onset on the left was associated to an increased frequency of depression (79\% x 50\%, non-significant). It has not been found any correlation between current affective state and metabolism in the frontal lobes, but it was interesting to observe that a history of depressive episodes (identified by SCID) significantly correlated with a left frontal lobe hypo metabolism. Hermann et al. [73] didn't find any correlation between humor and laterality, but a left-sided focus was significantly associated to the severity of frontal dysfunction (measured by Wisconsin Card Sort Test) and dysphoria. Contrarily, a right-sided focus was inversely associated to frontal dysfunction and dysphoria (non-significant results).

Our group studied 97 patients with TLE regarding risk factors for affective disorders [74]. A positive family history of psychiatric disorders (O.R. $=3.8 ; \mathrm{p}=0.003)$ and interictal EEG epileptiform discharges involving the left temporal lobe $($ O.R. $=2.9 ; \mathrm{p}=0.041)$ were significantly associated with an increased risk for an affective disorder in population studied. This article reinforced the importance 
of biological factors, specifically genetic and anatomical substrates, for the development of humor disorders in PWE.

Few studies evaluated the association between hippocampal volume loss, depression and epilepsy. Quiske et al. [75] found higher BDI scores in patients with TLE and hippocampal sclerosis, when compared to patients with normal MRI. Another study also identified an association between higher scores for depression and increased volume of left hippocampus, in patients with right hippocampal sclerosis [76]. Also studies with PET showed an association between higher scores for depression in PWE with metabolic alterations in temporal lobes, compared to PWE with normal PET [77].

\section{Anxiety disorders}

The main types of anxiety disorders described in DSM-IV are: generalized anxiety disorder, panic disorder, phobia, and obsessivecompulsive disorder. The risk factors pointed for the association between epilepsy and anxiety are: frequency of seizures, surgical treatment for epilepsy, age, type of seizure, and perception of stigma $[78,79]$.

Frequency of seizures was associated to anxiety in some works [80,81], but this is not an unanimity [82]. Studies combining PET with electrophysiological data indicate the right temporal lobe as the main structure responsible for pathogenesis of anxiety in epilepsy [83]. Probably, more than the frequency of seizures, fear of falling down or to die is the real critical factor for the development of anxiety in PWE. Surgical treatment for epilepsy may increase the frequency of anxiety disorders in these patients, especially those that experience a greater than $75 \%$ reduction in their seizures after surgery [84].

Regarding age, minimal effects were observed, although a late onset of epilepsy could be associated with higher degrees of anxiety [85]. Risk for anxiety seems to be greater in focal epilepsies (especially TLE) than in generalized epilepsies [86]. Higher indices of anxiety were found in patients with poor pharmacological control of their seizures $[87,88]$. An important factor linked to anxiety in PWE is the stigma perception $[89,90]$, and this factor is heavier in young patients $[83,91]$.

\section{Psychotic disorders}

Literature regarding risk factors for psychotic disorders in epilepsy is highly controversial, and most studies are restricted to interictal psychosis [92].

Regarding duration of epilepsy, in most series, time for the first psychotic manifestation from the onset of epilepsy is about 11 to 15 years, raising an etiological meaning to the epileptic disorder, through a mechanism "kindling-like" [40]. TLE is the epilepsy most associated with psychosis in almost all case series. In a non-systematic revision of 10 studies, 76\% patients suffering from psychosis had TLE [40]. Major criticism to these studies is that their results may reflect just the higher prevalence of TLE in the community. Severity of epilepsy is one of the most important risk factors for psychosis, and it could be measured by duration and multiplicity of seizures, history of status epilepticus, and poor clinical response to treatment [40]. Flor-Henry [93] originally suggested that left temporal lobe dysfunction was a risk factor for schizophreniform psychosis. Trimble's analysis of 14 studies with 341 patients with TLE found that $43 \%$ had a left-sided epileptic focus, $23 \%$ on the right, and $34 \%$ had bilateral changes [40]. This data regarding laterality were supported by neuroimaging studies, especially SPECT and MRI. Mellers et al. [94], using a verbal fluency activation paradigm and SPECT, compared patients with schizophrenia-like psychosis $(\mathrm{n}=$
12), schizophrenia $(\mathrm{n}=11)$, and non-psychotic epileptic patients $(\mathrm{n}=$ 16). Psychotic epileptic patients showed and increased blood flow in the superior temporal gyrus, during activation, related to the other groups. Maier et al. [95] compared the amygdalo-hippocampal volumes and hippocampal N-Acetyl Aspartate (NAA) (by spectroscopy) of patients with TLE, with $(\mathrm{n}=12)$ and without schizophreniform psychosis ( $=12)$, non-epileptic schizophrenics $(\mathrm{n}=26)$, and normal individuals $(n=38)$. Psychotic patients showed significant reduction of NAA in the left temporal lobe, with a more accentuated phenomenon observed in epileptic patients. PWE showed bilateral volume reduction, whereas psychotic patients had a more prominent atrophy of the left amygdalohippocampal complex.

Interictal psychosis seems to be different from schizophrenia, especially because interictal psychosis courses with more affective symptoms and has a better prognosis. Although hippocampal alterations could be related to both disorders, bilateral increase of amygdales (with less volumetric changes in hippocampi) is typical of interictal psychosis, suggesting a great difference between both conditions. This hypothesis was supported by a recent study, with 26 patients with epileptic psychosis, 24 non-psychotic patients with TLE, and 20 normal controls. Psychotic patients had significant bilateral increases of amygdales, in comparison with the other groups. These findings were not correlated with lateralization of the focus, and neither with the duration of epilepsy [96].

\section{Pshysiopathology \\ Bidirectional relation}

It is demonstrated that some specific humor and behavioral disorders may show a bidirectional relation with the onset of epileptic seizures, namely, a psychiatric diagnosis may precede onset of seizures, especially in three situations: major depression, suicidal ideation, and Attention Deficit Disorder with Hyperactivity (ADDH).

Case-control studies [97,98] as well as longitudinal studies [99], in children, showed an increased risk of 2.5 fold for patients with a diagnosis of ADDH suffer a first epileptic seizure.

Three controlled studies assessed the temporal relation between depression and epilepsy. One population-based case-control study found a 7 -fold increased risk for and adult with depression to develop epileptic seizures, ompared to normal individuals. The risk increased to 17-fold with focal epilepsies [49]. Hesdorffer et al. [100] observed the same temporal relation between depression and a first seizure, with a 6-fold increased risk. Data from these two studies were confirmed in a population-based controlled study, proceeded in Island, with 324 patients above 10 years of age, with a first non-provoked seizure or newly diagnosed epilepsy, and 647 controls: major depression, diagnosed after DSM-IV criteria, increased the risk for epilepsy in 1.7fold. This same atudy showed that a suicide temptation is associated with a 3.5-fold increased risk for epilepsy [16].

\section{Common physiopathologic mechanisms}

This bidirectionality suggests a common underlying susceptibility to epilepsy and humor disorders. Literature is plentiful of studies on molecular and cellular biology and anatomy of the brain in both diseases [101]. Thosemechanisms are strongly interconnected, and functional and structural alterations in one disease may give rise to the other.

Animal models: One of the best studied models in TLE uses 
convulsant substances, like kainate and pilocarpine, in general, systemically injected. After induce a status epilepticus in the animal, in this model, it follows a period of latency along some weeks, with further development of spontaneous seizures [102]. Other experimental model utilized is the electrical kindling, but this method does not seem to reproduce the typical physiopathological events of TLE, compared to the pharmacological method. With kindling, seizures do not occur spontaneously, a hippocampal sclerosis does not develop, and there is no latency period between initial precipitant injury and the development of seizures.

Recently, Mazaratti et al. [103] investigated if a kindling-induced chronic increase of susceptibility to seizures could result in a depressive behavior in rats. Two to four weeks after application of 84 subconvulsant electrical stimuli (each five minutes) in ventral hippocampus of adult Wistar rats, the authors applied two tests: Forced Swim Test (FST) and a gustative test (preference for sugar). Immobility in the tank on FST is equivalent to depression, as the animal does not show any initiative to escape in a stress situation. The second test aims to reproduce the loss of ability to seek pleasure, a frequent ymptom in depression. The study showed that rats submitted to kindling exhibited a significant increase in time of immobility on FST, associated to a loss of preference of sweet taste, compared to controls. The authors concluded that the alterations in neuronal plasticity caused by kindling would be followed by a depressive behavior. The role of neurotransmitters in the physiopathologic mechanisms of humor disorders is recognized since some decades ago [104].

The roles of gama-aminobutyric acid (GABA) and glutamate in epileptogenesis were already demonstrated in several studies in animals and humans. The Genetically Epilepsy-Prone Rat (GEPR) provides an experimental model for both epilepsy and depression. In this model, mutated animals are highly sensible to auditory stimuli, to which they answer with generalized tonic-clonic seizures. Moreover, GEPRs show endocrinologic changes similar to those identified in depressive patients: increased corticosteroid plasmatic levels, decreased secretion of growth hormone, and hypothyroidism [105]. Defective arborizations of noradrenergic and serotonergic circuitries were observed in those animals. An increase in the levels of these neurotransmitters could prevent seizures, whereas diminished levels have the opposite effect [105]. One classic study showed that fluoxetine, a selector synaptic serotonin reuptake inhibitor, provoked a dose-dependent reduction in the frequency of seizures in GEPRs, which correlated with extracellular thalamic serotonin concentrations [106].

Studies in humans: Animal serotonergic transmission was demonstrated in the brain of depressed patients [107,108], the same feature found in studies with PET, in patients with TLE $[109,110]$. In a more recent study, Hasler et al. [111] compared the level of 5-HT1A receptor binding to a specific antagonist, in 37 patients with TLE, with and without major depression (diagnosis by SCID), using PET. Beyond a decreased binding to 5-HT1A receptors in the epileptic focus, patients with major depression exhibited a more extensive reduction in binding, involving non-lymbic areas, distant from the epileptic focus.

One of the most important proteins involved in the functioning of Lymbic System is the BDNF. This element may influence both neuronal electrical activity and memory and behavior functions, which are directly related to hippocampus in its connections. Changes in BDNF are associated to hippocampus atrophy, alterations in memory, and temporary amygdalar hypertrophy, with alteration in fear process. Moreover, studies with PET suggest a glucose hypometabolism in temporal and frontal lobes in the TLE-depression association [112].

A functional polymorphism of BDNF gene, the Val66Met, has been studied as a predisposition factor for many neurological and psychiatric disorders, with variable results. Regarding epilepsy, it seems that there isn't any direct relation with the polymorphism [113]. Notwithstanding, depression, anxiety, psychosis and eating disorders have been often associated to the presence of Val66Met polymorphism in the BDNF gene [112]. A recent meta-analysis affirmed the association of Val66Met to substance-related disorders, eating disorders, and schizophrenia [114].

Our group also studied the association between 5HTTLPR and 5HTTVNTR allele variants in serotonin transporter gene and epileptogenesis in TLE. We compared 175 patients with TLE and 155 healthy control individuals, and observed an association between the presence of 5HTTLPR and 5-HTTVNTR less transcriptional efficient combined genotypes and TLE. Our results agreed with several other studies showing that low transcriptional activity 5-HTT genotypes are associated with neuropsychiatric disorders, such as depression, suicidal behavior, attention deficit hyperactivity disorder, and personality disorder [115].

\section{Discussion}

There is a growing evidence for psychiatric comorbidities in epilepsy. Studies on prevalence have demonstrated advances in methodological issues, improving reliability of results. Future research need to focus on physiopathologic mechanisms, especially regarding functional and structural alterations involving human neuronal circuitries in the Lymbic System. Although many studies on a possible association between epilepsy and the polymorphism of the BDNF gene, Val66Met, did not find any positive result, strong evidence exists linking this polymorphism to psychiatric disorders. Likely, serotonin allelic variants may also influence the modulation of serotoninergic system, and eventually epileptogenesis in TLE. For those reasons, it remains plausible to continue researching genetic variants in this field.

\section{References}

1. http://www.joydiv.org/iancurtis.htm\#biog

2. Elger CE, Schmidt D (2008) Modern management of epilepsy: a practical approach. Epilepsy Behav 12: 501-539.

3. Fisher RS, Van Emde BW, Blume W, Elger C, Genton P, et al. (2005) Epileptic seizures and epilepsy: definitions proposed by the International League Against Epilepsy (ILAE) and the International Bureau for Epilepsy (IBE). Epilepsia 46: 470-472.

4. (1981) Proposal for revised clinical and electroencephalographic classification of epileptic seizures. From the Commission on Classification and Terminology of the International League Against Epilepsy. Epilepsia 22: 489-501.

5. (1989) Proposal for revised classification of epilepsies and epileptic syndromes Commission on Classification and Terminology of the International League Against Epilepsy. Epilepsia 30: 389-399.

6. Engel J Jr (2001) Mesial temporal lobe epilepsy: what have we learned? Neuroscientist 7: 340-352.

7. Gaitatzis A, Trimble MR, Sander JW (2004) The psychiatric comorbidity of epilepsy. Acta Neurol Scand 110: 207-220.

8. Swinkels WA, Kuyk J, Van Dyck R, Spinhoven P (2005) Psychiatric comorbidity in epilepsy. Epilepsy Behav 7: 37-50.

9. Tellez-Zenteno JF, Patten SB, Jetté N, Williams J, Wiebe S (2007) Psychiatric comorbidity in epilepsy: a population- based analysis. Epilepsia 48: 2336-2344.

10. Christensen J, Vestergaard M, Mortensen PB, Sidenius P, Agerbo E (2007) Epilepsy and risk of suicide: a population- based case-control study. Lancet Neurol 6: 693-698. 
Citation: Bragatti JA, Torres CM, Isolan GR, Bianchin MM (2011) Psychiatric Comorbidities of Epilepsy: A Review. J Neurol Neurophysiol S2. doi:10.4172/2155-9562.S2-002

11. Temkin O (1971) The falling sickness. (2ndedn), The John Hopkins Press, Baltimore.

12. Jones JE, Hermann B, Barry JJ, Gilliam F, Kanner AM, et al. (2005) Clinica assessment of axis I psychiatric morbidity in chronic epilepsy: a multicenter investigation. J Neuropsychiatry Clin Neurosci 17: 172-179.

13. Bijl RV, Ravelli A, Van Zessen G (1998) Prevalence of psychiatric disorder in the general population results of The Netherlands Mental Health Survey and Incidence Study (NEMESIS). Soc Psychiatry Psychiatr Epidemiol 33: 587-595.

14. Marcangelo MJ, Ovsiew F (2007) Psychiatric aspects of epilepsy. Psychiatr Clin North Am 30: 781-802.

15. Kanner AM (2008) Mood disorder and epilepsy: a neurobiologic perspective of their relationship. Dialogues Clin Neurosci 10: 39-45

16. Hesdorffer DC, Hauser WA, Olafsson E, Ludvigsson P, Kjartansson O (2006) Depression and suicide attempt as risk factors for incident unprovoked seizures. Ann Neurol 59: 35-41.

17. Lindvall O, Kokaia Z, Bengzon J, Elmér E, Kokaia M (1994) Neurotrophins and brain insults. Trends Neurosci 17: 490-496.

18. Koyama R, Ikegaya Y (2005) To BDNF or not to BDNF: that is the epileptic hippocampus. Neuroscientist 11: 282-287.

19. Rosenow F, Lüders H (2001) Presurgical evaluation of epilepsy. Brain 124: 1683-1700.

20. McCormick DA, Contreras D (2001) On the cellular and network bases of epileptic seizures. Annu Rev Physiol 63: 815-846.

21. Kostopoulos IA, van Merode T, Kessels FG, de Krom MC, Knottnerus JA (2002) Systematic review and meta-analysis of incidence studies of epilepsy and unprovoked seizures. Epilepsia 43:1402-1409.

22. Heaney DC, Macdonald BK, Everitt A, Stevenson S, Leonardi GS, et al. (2002) Socioeconomic variation in incidence of epilepsy: prospective community based study in south east England. BMJ 325: 1013-1016.

23. Jallon P (2002) Epilepsy and epileptic disorders, an epidemiological marker? Contributions of descriptive epidemiology. Epileptic Disord 4: 1-13.

24. Sander JW (2003) The epidemiology of epilepsy revisited. Curr Opin Neuro 16: $165-170$

25. Sander JW (1993) Some aspects of prognosis in the epilepsies: a review Epilepsia 34: 1007-1016

26. Cockerell OC, Johnson AL, Sander JW, Shorvon SD (1997) Prognosis of epilepsy: a review and further analysis of the first nine years of the British National General Practice Study of Epilepsy, a prospective population-based study. Epilepsia 38: 31-46.

27. Rafnsson V, Olafsson E, Hauser WA, Gudmundsson G (2001) Cause-specific mortality in adults with unprovoked seizures: a population-based incidence cohort study. Neuroepidemiology 20: 232-236.

28. Camfield CS, Camfield PR, Veugelers PJ (2002) Death in children with epilepsy: a population-based study. Lancet 359: 1891-1895.

29. Guerreiro C, Cendes F, Li LM, Jones-Gotman M, Andermann F, et al. (1999) Clinical patterns of patients with temporal lobe epilepsy and pure amygdalar atrophy. Epilepsia 40: 453-461.

30. Gomes MM, Zeitoune RG, Kropf LA, Beeck ES (2002) A house-to-house survey of epileptic seizures in an urban community of Rio de Janeiro, Brazil. Arq Neuropsiquiatr 60: 708-711.

31. So EL (2006) Value and limitations of seizure semiology in localizing seizure onset. J Clin Neurophysiol 23: 353-357.

32. Jam MM, Girvin JP (2008) Seizure semiology: value in identifying seizure origin. Can J Neurol Sci 35: 22-30

33. Wiebe S, Blume WT, Girvin JP, Eliasziw M (2001) A randomized, controlled trial of surgery for temporal lobe epilepsy. N Engl J Med 345: 311-318.

34. Foldvary N, Lee N, Thwaites G, Mascha E, Hammel J, et al. (1997) Clinical and electrographic manifestations of lesional neocortical temporal lobe epilepsy. Neurology 49: 757-763.
35. Lahl R, Villagran R, Teixeira W (2003) Neuropathology of Focal Epilepsies: an atlas. Glasgow: John Libbey.

36. Bertram EH (2009) Temporal lobe epilepsy: where do the seizures really begin? Epilepsy Behav 14: 32-37.

37. Feinstein AR (1970) The pretherapeutic classification of comorbidity in chronic disease. Journal of Chronic Diseases 23: 455-468.

38. Hermann B, Seidenberg M, Jones J (2008) The neurobehavioural comorbidities of epilepsy: can a natural history be developed? Lancet Neurol 7: 151-160.

39. Krishnamoorthy ES, Reghu R (2007) The psychoses of epilepsyPhiladelphia: Lippincott Williams \& Wilkins

40. Trimble MR (1991) The psychoses of epilepsy. New York, USA

41. Blumer DP (2008) Interictal Dysphoric Disorder. New York, USA.

42. Landolt H (1953) Some clinical electroencephalographical correlations in epileptic psychoses (twilight states). Electroencephalogr Clin Neurophysiol 5

43. Slater E, Beard AW, Glithero E (1963) The schizophrenia-like psychoses of epilepsy. Br J Psychiatry 109: 95-150

44. Gudmundsson G (1966) Epilepsy in Iceland. A clinical and epidemiological investigation. Acta Neurol Scand 43: 1- 124

45. Rutter M, Graham P, Yule W (1970) A neuropsychiatric study in childhood Clinics in developmental medicine. Heinemann/SIMP, London.

46. Havlova M (1990) Prognosis in childhood epilepsy. Acta Univ Carol Med Monogr 135: 1-105.

47. Forsgren L, Nystrom L (1990) An incident case-referent study of epileptic seizures in adults. Epilepsy Res 6: 66-81.

48. Kessler RC, McGonagle KA, Zhao S, Nelson CB, Hughes M, et al. (1994) Lifetime and 12-month prevalence of DSM-III-R psychiatric disorders in the United States: results from the National Comorbidity Survey. Arch Gen Psychiatry 51: 8-19.

49. Jalava M, Sillanpaa M (1996) Concurrent illnesses in adults with childhoodonset epilepsy: a population-based 35-year follow-up study. Epilepsia 37 1155-1163.

50. Offord DR, Boyle MH, Campbell D, Goering P, Lin E, et al. (1996) One-yea prevalence of psychiatric disorders in Ontarians 15 to 64 years of age. Can $J$ Psychiatry 41: 559-563.

51. Hackett R, Hackett L, Bhakta P (1998) Psychiatric disorder and cognitive function in children with epilepsy in Kerala, South India. Seizure 7: 321-324.

52. Mensah SA, Beavis JM, Thapar AK, Kerr M (2006) The presence and clinica implications of depression in a community population of adults with epilepsy. Epilepsy Behav 8: 213-219.

53. Kobau R, Gilliam F, Thurman DJ (2006) Prevalence of self-reported epilepsy or seizure disorder and its associations with self-reported depression and anxiety: results from the 2004 Health Styles Survey. Epilepsia 47: 1915-1921.

54. Edeh J, Toone B (1987) Relationship between interictal psychopathology and the type of epilepsy. Results of a survey in general practice. $\mathrm{Br} \mathrm{J}$ Psychiatry 151: 95-101.

55. First MB, Spitzer RL, Gibbon M, Williams J (2001) Structured Clinical Interview for DSM-IV - TR Axis I disorders, New York, USA

56. Sheehan DV, Lecrubier Y, Sheehan KH, Amorim P, Janavs J, et al. (1998) The Mini-International Neuropsychiatric Interview (M.I.N.I.): the development and validation of a structured diagnostic psychiatric interview for DSM-IV and ICD10. J Clin Psychiatry 59: 22-33.

57. Beck AT, Steer RA, Brown GK (1996) Beck Depression Inventory Manual. (2ndedn), The Psychological Corporation, San Antonio.

58. Radloff LS (1977) The CES-D scale: a self-report depression scale for research in the general population. J Applied Psychol Measurement 1: 385-401.

59. Sandanger I, Nygard JF, Ingebrigtsen G, Sørensen T, Dalgard OS (1999) Prevalence, incidence and age at onset of psychiatric disorders in Norway. Soc Psychiatry Psychiatr Epidemiol 34: 570-579. 
Citation: Bragatti JA, Torres CM, Isolan GR, Bianchin MM (2011) Psychiatric Comorbidities of Epilepsy: A Review. J Neurol Neurophysiol S2. doi:10.4172/2155-9562.S2-002

60. Jones JE, Bell B, Fine J, Rutecki P, Seidenberg M, et al. (2007) A controlled prospective investigation of psychiatric comorbidity in temporal lobe epilepsy. Epilepsia 48: 2357-2360

61. Manchanda R, Schaefer B, McLachlan R, Blume WT (1992) Interictal psychiatric morbidity and focus of epilepsy in treatment-refractory patients admitted to an epilepsy unit. Am J Psychiatry 149: 1096-1098.

62. Swinkels WA, Kuyk J, De Graaf EH, van Dyck R, Spinhoven P (2001) Prevalence of psychopathology in Dutch epilepsy inpatients: a comparative study. Epilepsy Behav 2: 441-447.

63. Lambert MV, Robertson MM (1999) Depression in epilepsy: etiology, phenomenology, and treatment. Epilepsia 40: S21-S47.

64. De Boer HM, Mula M, Sander JW (2008) The global burden and stigma of epilepsy. Epilepsy Behav 12: 540-546.

65. Tebartz van Elst L, Trimble MR (2004) Depression but not seizure frequency predicts quality of life in treatment-resistant epilepsy. Neurology 63: 942-943.

66. Hurwitz TA, Wada JA, Kosaka BD, Strauss EH (1985) Cerebral organization of affect suggested by temporal lobe seizures. Neurology 35: 1335-1337.

67. Bear DM, Fedio P (1977) Quantitative analysis of interictal behavior in temporal lobe epilepsy. Arch Neurol 34: 454-467.

68. Robertson MM, Trimble MR, Townsend HR (1987) Phenomenology of depression in epilepsy. Epilepsia 28: 364-372.

69. Altshuler LL, Devinsky O, Post RM, Theodore W (1990) Depression, anxiety and temporal lobe epilepsy. Arch Neurol 47: 282-288.

70. Victoroff JI, Benson F, Grafton ST, Engel J Jr, Mazziotta JC (1994) Depression in complex partial seizures: electroencephalography and cerebral metabolic correlates. Arch Neurol 51: 155-163.

71. Helmstaedter C, Sonntag-Dillender M, Hoppe C, Elger CE (2004) Depressed mood and memory impairment in temporal lobe epilepsy as a function of focus lateralization and localization. Epilepsy Behav 5: 696-701.

72. Bromfield EB, Altshuler L, Leideran DB, Balish M, Ketter TA, et al. (1992) Cerebral metabolism and depression in patients with complex partial seizures. Arch Neurol 49: 617-623.

73. Hermann BP, Seidenberg M, Haltiner A, Wyler AR (1991) Mood state in unilateral temporal lobe epilepsy. Biol Psychiatry 30: 1205-1218.

74. Bragatti JA, Torres CM, Assmann JB, Fontana V, Rigotti CP, et al. (2009) Leftsided EEG focus and positive psychiatric family history are independent risk factors for affective disorders in temporal lobe epilepsy. Epilepsy Res 87: 169176.

75. Quiske A, Helmstaedter C, Lux S, Elger CE (2000) Depression in patients with temporal lobe epilepsy is related to mesial temporal sclerosis. Epilepsy Res 39: $121-125$

76. Baxendale SA, Thompson PJ, Duncan JS (2005) Epilepsy and depression: the effects of comorbidity on hippocampal volume - a pilot study. Seizure 14 $435-438$

77. Gilliam FG, Santos J, Vahle V, Carter J, Brown K, et al. (2004) Depression in epilepsy: ignoring clinical expression of neuronal network dysfunction? Epilepsia 45: 28-33.

78. Vazquez B, Devinsky O (2003) Epilepsy and anxiety. Epilepsy Behav 4 S20-S25.

79. Beyenburg S, Mitchell AJ, Schmidt D, Elger CE, Reuber M (2005) Anxiety in patients with epilepsy: systematic review and suggestions for clinical management. Epilepsy Behav 7: 161-171.

80. Smith DF, Baker GA, Dewey M, Jacoby A, Chadwick DW (1991) Seizure frequency, patient-perceived seizure severity and the psychosocial consequences of intractable epilepsy. Epilepsy Res 9: 231-241.

81. Jacoby A, Baker GA, Steen N, Potts P, Chadwick DW (1996) The clinical course of epilepsy and its psychosocial correlates: findings from a U.K. community study. Epilepsia; 37: 148-161.

82. Choi-Kwon S, Chung C, Kim H, Lee S, Yoon S, et al. (2003) Factors affecting the quality of life in patients with epilepsy in Seoul, South Korea. Acta Neuro Scand 108: 428-434

83. Harden CL, Goldstein MA, Ettinger AB (2007) Anxiety disorders in epilepsy Psychiatric Issues in Epilepsy: a practical guide to diagnosis and treatment Lippincott Williams \& Wilkins, Philadelphia

84. Malmgren K, Sullivan M, Ekstedt G, Kullberg G, Kumlien E (1997) Healthrelated quality of life after epilepsy surgery: a Swedish multi-center study. Epilepsia 38: 830-838

85. Jacoby A, Buck D, Baker G, McNamee P, Graham-Jones S, et al. (2001) The quality of life of older people with epilepsy: findings from a U.K. community study. Seizure 10: 92-99.

86. Piazzini A, Cavenini MP, Maggiori G, Canger R (2001) Depression and anxiety in patients with epilepsy. Epilepsy Behav 2: 481-489.

87. Hermann BP, Seidenberg M, Bell B (2000) Psychiatric comorbidity in chronic epilepsy: identification, consequences, and treatment of major depression. Epilepsia 41: S31-S41.

88. Kanner AM (2003) Depression in epilepsy: prevalence, clinical semiology, pathogenic mechanisms, and treatment. Biol Psychiatry 54: 388-398.

89. Adewuya AO, Ola BA (2005) Prevalence of and risk factors for anxiety and depressive disorders in Nigerian adolescents with epilepsy. Epilepsy Behav 6: 342-347.

90. Jacoby A, Snape D, Baker GA (2005) Epilepsy and social identity: the stigma of a chronic neurological disorder. Lancet Neurol 4: 171-178.

91. Baker GA, Brooks J, Buck D, Jacoby A (2000) The stigma of epilepsy: a European perspective. Epilepsia 41: 98-104

92. Schmitz B, Trimble M. (2008) Psychosis and forced normalization. Demos New York

93. Flor-Henry P (1969) Psychosis and temporal lobe epilepsy: a controlled investigation. Epilepsia 10: 363-395

94. Mellers JD, Adachi N, Takei N, Cluckie A, Toone BK, (1998) SPECT study of verbal fluency in schizophrenia and epilepsy. Br J Psychiatry173: 69-74.

95. Maier M, Mellers J, Toone B, Trimble M, Ron MA (2000) Schizophrenia temporal lobe epilepsy and psychosis: an in vivo magnetic resonance spectroscopy and imaging study of the hippocampus/amygdala complex. Psychol Med 30: 571-581.

96. Tebartz Van Elst L, Baeumer D, Lemieux L, Woermann FG, Koepp M, et al (2002) Amygdala pathology in psychosis of epilepsy: a magnetic resonance imaging study in patients with temporal lobe epilepsy. Brain 125: 140-149.

97. Dunn DW, Austin JK, Huster GA (1997) Behavior problems in children with new-onset epilepsy. Seizure 6: 283-287.

98. Austin JK, Harezlak J, Dunn DW, Huster GA, Rose DF, et al. (2001) Behavior problems in children before first recognized seizures. Pediatrics 107: 115-122.

99. Hesdorffer DC, Ludvigsson P, Olafsson E, Gudmundsson G, Kjartansson O, et al. (2004) ADHD as a risk factor for incident unprovoked seizures and epilepsy in children. Arch Gen Psychiatry 61: 731-736.

100. Hesdorffer DC, Hauser WA, Annegers JF, Cascino G (2000) Major depression is a risk factor for seizures in older adults. Ann Neurol 47: 246-249.

101. Kondziella D, Alvestad S, Vaaler A, Sonnewald U (2007) Which clinical and experimental data link temporal lobe epilepsy with depression? J Neurochem 103: 2136-2152.

102. Coulter D, McIntyre D, Loscher W (2002) Animal models of limbic epilepsies: what can they tell us? Brain Pathol 12: 240-256.

103. Mazarati A, Shin D, Auvin S, Caplan R, Sankar R (2007) Kindling epileptogenesis in immature rats leads to persistent depressive behavior Epilepsy Behav 10: 377-383.

104. Schildkraut JJ (1965) The catecholamine hypothesis of effective disorders: a review of supporting evidence. Am J Psychiatry 122: 509-522.

105. Jobe PC, Weber RH (2006) Affective disorder and epilepsy comorbidity in 
Citation: Bragatti JA, Torres CM, Isolan GR, Bianchin MM (2011) Psychiatric Comorbidities of Epilepsy: A Review. J Neurol Neurophysiol S2. doi:10.4172/2155-9562.S2-002

Page 10 of 10

the genetically epilepsy prone-rat (GEPR). Depression and Brain Dysfunction. London, Taylor \& Francis, UK.

106. Yan QS, Jobe PC, Dailey JW (1993) Evidence that a serotonergic mechanism is involved in the anticonvulsant effect of fluoxetine in genetically epilepsy prone rats. Eur J Pharmacol 252: 105-112.

107. Nemeroff CB, Knight DL, Krishnan RR, Slotkin TA, Bissette G, et al. (1988) Marked reduction in the number of platelet-tritated imipramine binding sites in geriatric depression. Arch Gen Psychiatry 45: 919-923.

108. Malison RT, Price LH, Berman R, van Dyck CH, Pelton GH, et al. (1998) Reduced brain serotonin transporter availability in major depression as measured by[123I]-2 beta-carbomethoxy- 3 beta-(4-iodophenyl)tropane and single photon emission computed tomography. Biol Psychiatry 44: 1090-1098.

109. Drevets WC, Frank E, Price JC, Kupfer DJ, Holt D, et al. (1999) PET imaging of serotonin $1 \mathrm{~A}$ receptor binding in depression. Biol Psychiatry 46: 1375-1387.

110. Sargent PA, Kjaer KH, Bench CJ, Rabiner EA, Messa C, et al. (2000) Brain serotonin $1 \mathrm{~A}$ receptor binding measured by positron emission tomography with.[11C]WAY-100635: effects of depression and antidepressant treatment. Arch Gen Psychiatry 57: 174-180.
111. Hasler G, Bonwetsch R, Giovacchini G, Toczek MT, Bagic A, et al. (2007) 5-HT1A receptor binding in temporal lobe epilepsy patients with and without major depression. Biol Psychiatry 62: 1258-1264.

112. Bath KG, Lee FS (2006) Variant BDNF (Val66Met) impact on brain structure and function. Cogn Affect Behav Neurosci 6: 79-85.

113. Bragatti JA, Schenkel LC, Torres CM, Manfro GG, Blaya C, et al. (2010) No major clinical impact of Val66Met BDNF gene polymorphism on temporal lobe epilepsy. Epilepsy Res 88: 108-111.

114. Gratacòs M, González JR, Mercader JM, de Cid R, Urretavizcaya M, et al (2007) Brain-derived neurotrophic factor Val66Met and psychiatric disorders: meta-analysis of case-control studies confirm association to substance-related disorders, eating disorders, and schizophrenia. Biol Psychiatry 61: 911-922.

115. Schenkel LC, Bragatti JA, Torres CM, Martin KC, Gus-Manfro G, et al (2011) Serotonin transporter gene (5HTT) polymorphisms and temporal lobe epilepsy. Epilepsy Res 95: 152-157. 